\title{
Three-Dimensional Geologic Model of Complex Fault Structures in the Upper Seco Creek Area, Medina and Uvalde Counties, South-Central Texas
}

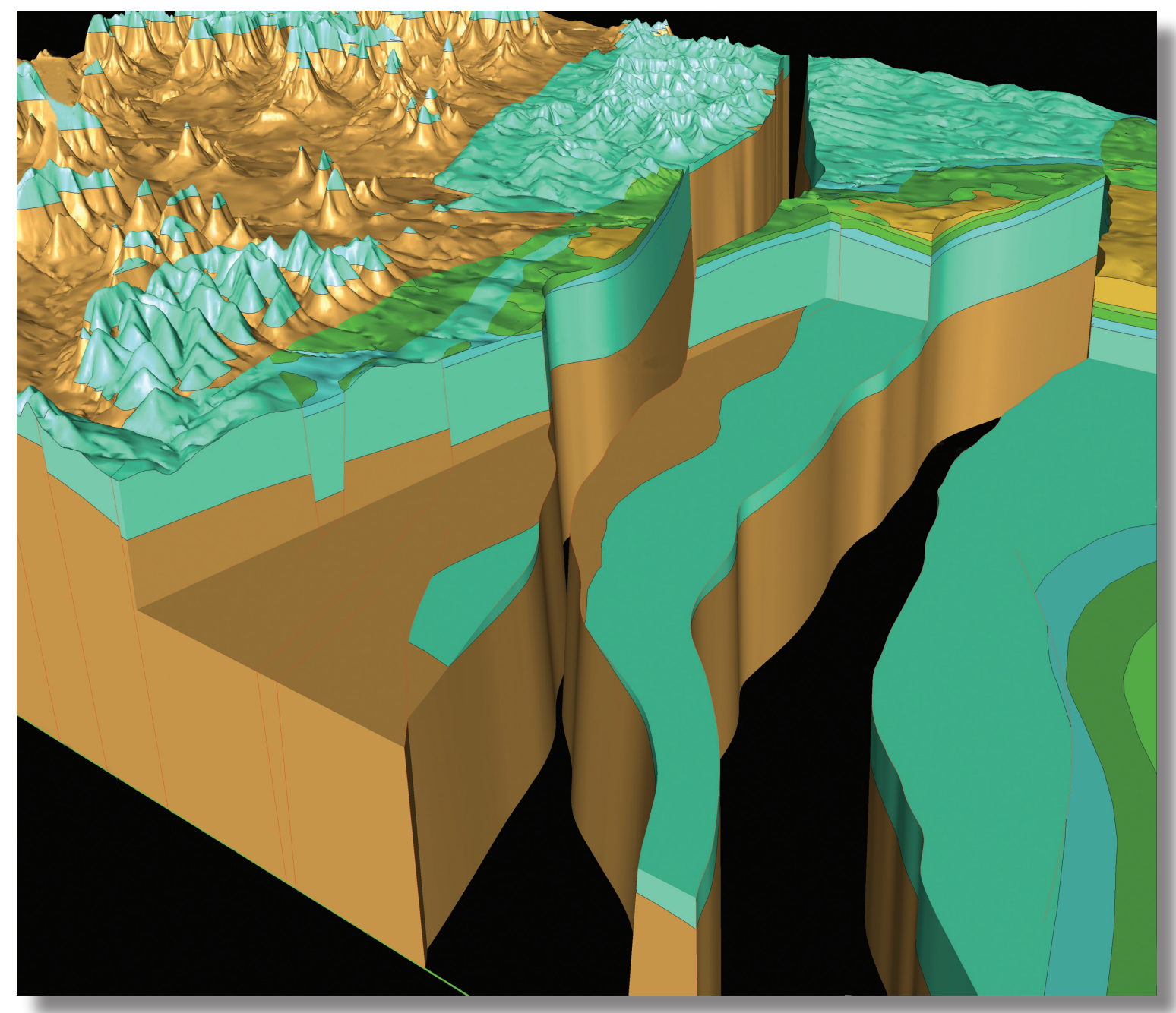

Scientific Investigations Report 2008-5131 



\section{Three-Dimensional Geologic Model of Complex Fault Structures in the Upper Seco Creek Area, Medina and Uvalde Counties, South-Central Texas}

By Michael P. Pantea, James C. Cole, Bruce D. Smith, Jason R. Faith, Charles D. Blome, and David V. Smith

Scientific Investigations Report 2008-5131 


\title{
U.S. Department of the Interior DIRK KEMPTHORNE, Secretary
}

\author{
U.S. Geological Survey \\ Mark D. Myers, Director
}

U.S. Geological Survey, Reston, Virginia: 2008

For product and ordering information:

World Wide Web: http://Www.usgs.gov/pubprod

Telephone: 1-888-ASK-USGS

For more information on the USGS - the Federal source for science about the Earth, its natural and living resources, natural hazards, and the environment:

World Wide Web: http://www. usgs.gov

Telephone: 1-888-ASK-USGS

Any use of trade, product, or firm names is for descriptive purposes only and does not imply endorsement by the U.S. Government.

Although this report is in the public domain, permission must be secured from the individual copyright owners to reproduce any copyrighted materials contained within this report.

Suggested citation:

Pantea, M.P., Cole, J.C., Smith, B.D., Faith, J.R., Blome, C.D., and Smith, D.V., 2008, Three-dimensional geologic model of complex fault structures in the upper Seco Creek area, Medina and Uvalde Counties, South-Central Texas: U.S. Geological Survey Scientific Investigations Report 2008-5131, DVD-ROM, 9 p. 


\section{Contents}

Abstract
Introduction
Geologic Setting
Modeled and Mapped Stratigraphy and Lithologic Descriptions
Model Construction and Methodology
Structural Uncertainties in Southeastern Part of Model
Modeled Structure
Conclusions
References Cited.
Disc Contents.

\section{Figures}

1. Index map showing the location of the model defined by the quadrangles used and part of the Balcones fault zone within the upper Seco Creek area of Medina and Uvalde Counties, south-central Texas

2. Correlation chart showing relationships of the geologic and hydrogeologic units used in the model. The Anacacho Limestone and Austin Group (Chalk) are combined in the model.

3. Surface of the Glen Rose Limestone showing the inferred north-trending fault bounded by the discontinuous Seco Valley Road fault on the north and the continuous Parker Creek fault on the south 



\title{
Three-Dimensional Geologic Model of Complex Fault Structures in the Upper Seco Creek Area, Medina and Uvalde Counties, South-Central Texas
}

\author{
By Michael P. Pantea, James C. Cole, Bruce D. Smith, Jason R. Faith, Charles D. Blome, and David V. Smith
}

\begin{abstract}
This multimedia report shows and describes digital three-dimensional faulted geologic surfaces and volumes of the lithologic units of the Edwards aquifer in the upper Seco Creek area of Medina and Uvalde Counties in south-central Texas. This geologic framework model was produced using (1) geologic maps and interpretations of depositional environments and paleogeography; (2) lithologic descriptions, interpretations, and geophysical logs from 31 drill holes; (3) rock core and detailed lithologic descriptions from one drill hole; (4) helicopter electromagnetic geophysical data; and (5) known major and minor faults in the study area. These faults were used because of their individual and collective effects on the continuity of the aquifer-forming units in the Edwards Group. Data and information were compared and validated with each other and reflect the complex relationships of structures in the Seco Creek area of the Balcones fault zone.

This geologic framework model can be used as a tool to visually explore and study geologic structures within the Seco Creek area of the Balcones fault zone and to show the connectivity of hydrologic units of high and low permeability between and across faults. The software can be used to display other data and information, such as drill-hole data, on this geologic framework model in three-dimensional space.
\end{abstract}

\section{Introduction}

The Edwards aquifer is one of the most permeable and productive carbonate aquifers in the United States and is designated a sole source aquifer by the U.S. Environmental Protection Agency. The Edwards aquifer is important to the livelihood of south-central Texas residents and serves the domestic, industrial, agricultural, and recreational needs of nearly 2 million people. It is the major source of water for the city of San Antonio, Texas, the seventh-largest city in the United States.

This three-dimensional model shows integrated geologic data of the Edwards aquifer hydrostratigraphic units and structural features within a study area composed of four 7.5-minute quadrangles: Comanche Waterhole, Flatrock Crossing, Sabinal NE, and Texas Mountain (fig. 1). The model evolved using Dynamic Graphics EarthVision ${ }^{\mathrm{TM}}$ software and shows faulted hydrogeologic surfaces representing data from drill holes and rock core, mapped geologic surfaces, faults and other geologic structures; geologic contacts mapped from aerial photography; and helicopter electromagnetic survey (HEM) geophysical data. The HEM survey of the study area was conducted in the spring of 2002 (Smith and others, 2003) to identify and map subsurface geologic features. Drill-hole data and mapped surface contacts were used to confirm the HEM-defined surfaces.

Goals of this study were to provide scientific information to a nontechnical audience and integrate different geoscience data types to accurately represent the local faulted geologic units that form the Edwards aquifer. Integrating different geoscience data types made the model internally consistent because drill-hole data helped to confirm HEM and surface geologic data, surface geologic data helped to confirm HEM and drill-hole data, and HEM data helped to confirm drillhole and surface geologic data. The resultant model is a more accurate interpretation due to the diversity, integration, and cross-validation of the data types.

We developed this visual interactive tool for the nontechnical and technical audience to show and help evaluate the shape and form of the lithologies that define the Edwards aquifer within the study area. The model shows some properties of the geologic framework that may affect the behavior of the aquifer: (1) the complex relationships between fault-bounded lithologic units, (2) possible downgradient flow pathways along or across fault boundaries, and (3) possible downgradient flow pathways along the tilted and fractured ramplike structures created by unequal displacement of faults within this part of the Balcones fault zone.

\section{Geologic Setting}

The Edwards aquifer lies within the Balcones fault zone. Stratigraphic units that compose the aquifer host numerous subparallel, northeast-trending, near-vertical normal faults that are downthrown to the southeast. Locally, major faults 


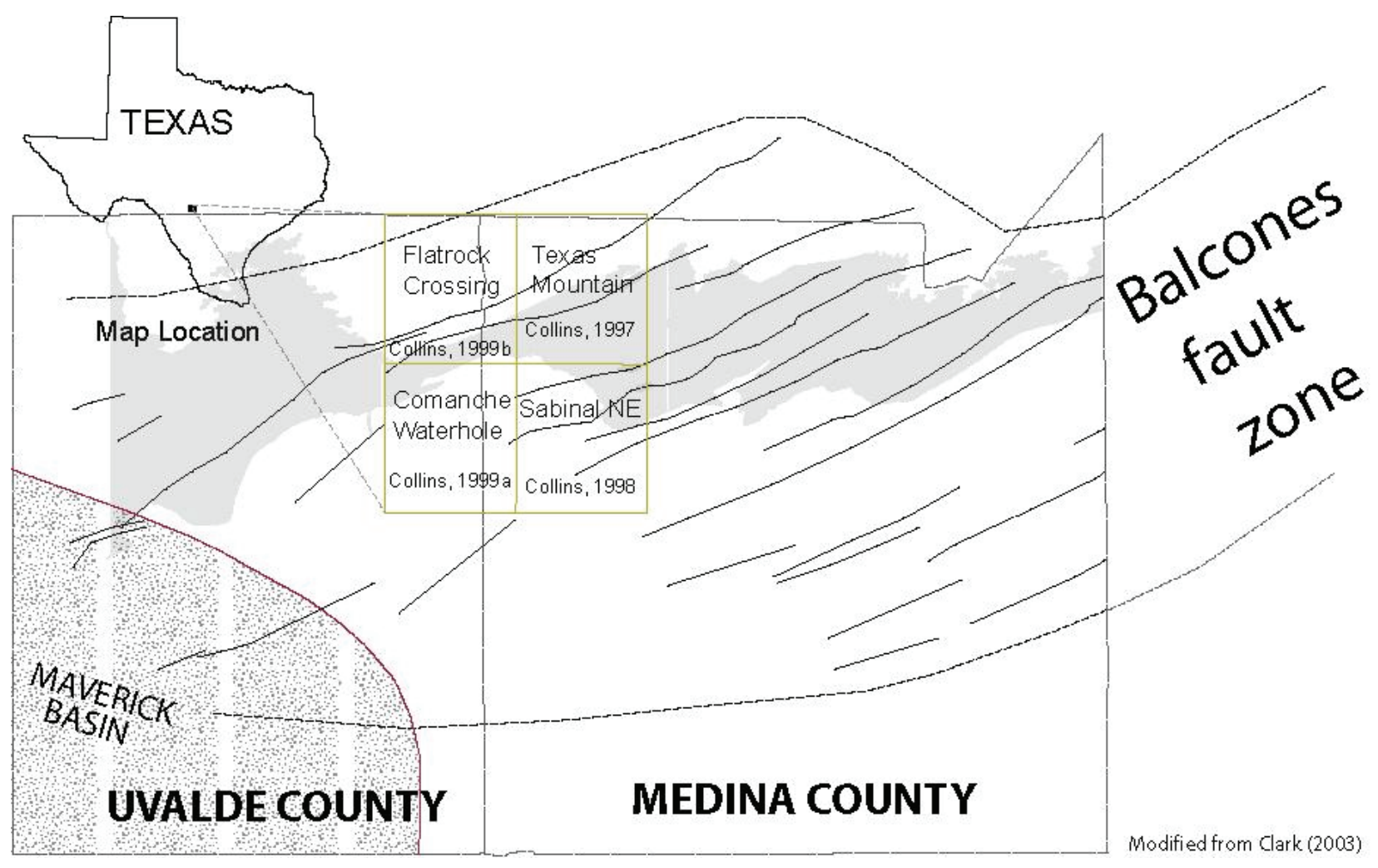

Figure 1. Index map showing the location of the model defined by the quadrangles used and part of the Balcones fault zone within the upper Seco Creek area of Medina and Uvalde Counties, south-central Texas.

may be connected by southeast-trending cross-faults shown by Clark (2003), Small and Clark (2000), and other workers. Locally and regionally, faults within the Balcones fault zone of south-central Texas have significant effect on the hydrogeology of the Edwards aquifer by (1) acting as areas of enhanced waterflow parallel to the faults where porosity and permeability are increased and (or) (2) acting as barriers preventing or restricting downgradient waterflow.

This three-dimensional (3-D) model is made up of, and shows, geologic units that confine the Edwards aquifer (fig. 2). The lowermost confining unit shown in the model is the upper member of the Glen Rose Limestone. Hydrogeologic units of the Edwards aquifer include the Devils River Formation of the Devils River trend and the overlying thin, discontinuous Georgetown Formation (Clark, 2003), not separately shown in the model. The uppermost confining unit shown in the model is the Del Rio Clay.

Exposed stratigraphy in the Seco Creek area extends from the Lower Cretaceous Glen Rose Limestone to the Quaternary alluvium and terrace gravels (not shown in the model). The Edwards Group (Devils River Formation) are reefal-facies lithologies, very porous and permeable, dolomitized, rudist-bearing limestone containing shell fragments that formed along the western, northern, and eastern margins of the Maverick Basin (fig. 1) as described by Lozo and Smith (1964).
The Lower Cretaceous units shown in the model are the Glen Rose Limestone and Devils River Formation of the Edwards Group. The Glen Rose Limestone is shown as a single unit in the model; however, it is informally subdivided into upper and lower members by Stricklin and Amsbury (1974). Upper Cretaceous stratigraphy modeled from youngest to oldest are the Anacacho Limestone and Austin Group (undivided), the Eagle Ford Formation, the Buda Formation, and the Del Rio Clay. A younger Upper Cretaceous mafic intrusive unit in the southwest corner of the model penetrates all modeled units. Details about the geologic setting and stratigraphic relationships are beyond the scope of this model and are described by others such as Lozo and Smith (1964), Collins (1997, 1998, 1999a, 1999b), and Blome and others (2004).

\section{Modeled and Mapped Stratigraphy and Lithologic Descriptions}

The following brief descriptions of rock units modeled were compiled from different sources that include Collins (1997); Small and Clark (2000); Clark (2003); and Blome and others (2004). 


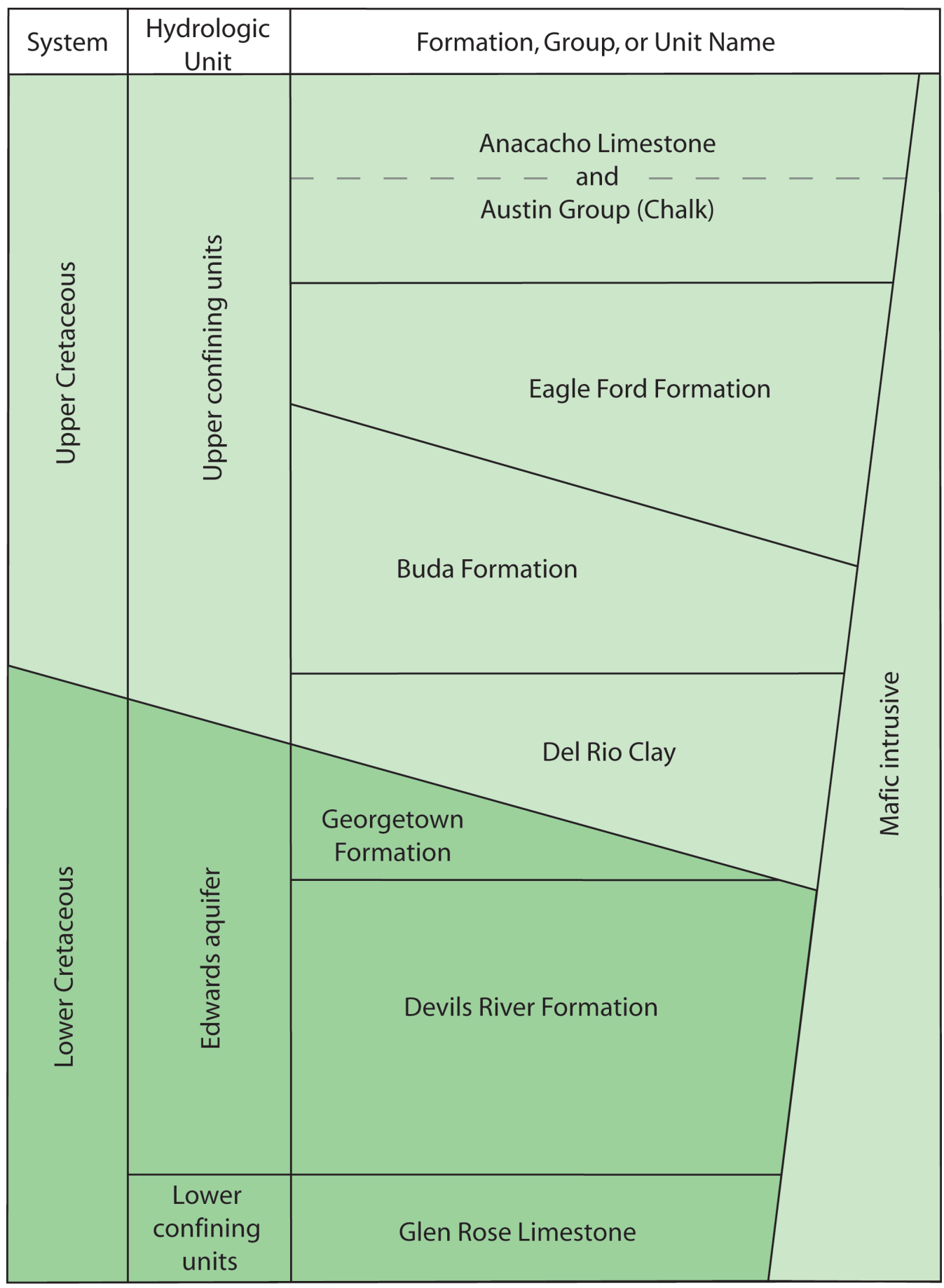

Figure 2. Correlation chart showing relationships of the geologic and hydrogeologic units used in the model. The Anacacho Limestone and Austin Group (Chalk) are combined in the model. 
The upper member of the Glen Rose Limestone is greater than $500 \mathrm{ft}(152 \mathrm{~m})$ thick and is the lower confining unit of the Edwards aquifer. The Glen Rose consists of alternating beds of light-gray to yellowish-brown limestone, dolomitic and argillaceous limestone, and marl. Locally, the unit includes packstone to grainstone and collapsed sedimentary breccia. Local fossil assemblage includes oysters, gastropods, foraminifers, and dinosaur tracks. This unit extends to the base of the model and was not defined by thickness.

The Devils River Formation (undivided in the model) varies from 500 to $600 \mathrm{ft}(152-183 \mathrm{~m})$ in thickness and is informally divided into upper and lower units. Within the study area, the upper unit thickness varies from 200 to $250 \mathrm{ft}$ (61-76 m), and the lower unit thickness varies from 300 to $350 \mathrm{ft}$ (91-107 m). The lower unit unconformably overlies the upper Glen Rose Limestone and is composed of limestone and dolomitic limestone with local breccia. The lower one-half of the unit may contain sparry limestone and burrowed mudstone that locally hosts gastropods, miliolids, and pelecypods. The upper part of this unit is composed of limestone and dolomitic limestone with shell fragments supported by grainstone. Locally, the upper part of the Devils River Formation may have interfingered beds of the Georgetown Formation (Small and Clark, 2000).

The Del Rio Clay is about $60 \mathrm{ft}(18 \mathrm{~m})$ thick and is the upper confining unit of the Edwards aquifer. The Del Rio Clay shares an abrupt unconformable contact with the underlying Devils River Formation. The unit is gypsiferous, calcareous, poorly indurated clay with beds of pelecypods. Locally, the Del Rio Clay contains thin, lenticular, calcareous siltstone beds.

The Buda Formation is variable in thickness, averaging $70 \mathrm{ft}(21 \mathrm{~m})$ between the top Del Rio Clay and the bottom of the Eagle Ford Formation. Where exposed, the unit is lightgray to pale-orange, poorly bedded to nodular, hard to chalky mudstone containing abundant pelecypods, foraminifers, and ostracodes; solitary corals and algae are common.

The Eagle Ford Formation is about $40 \mathrm{ft}(12 \mathrm{~m})$ thick and consists of flaggy, sandy shale, siltstone, and argillaceous limestone. The base of the group commonly contains oysters, ostracodes, and fossil fish. The lower part of the unit commonly is laminated siltstone that grades upward to silty limestone and shale.

The youngest rock units modeled are the Upper Cretaceous Anacacho Limestone and the Austin Group locally known as the Austin Chalk. These units are not differentiated in the model due to poor surface exposures and subsurface contact information. The Austin Group varies from 135 to 200 $\mathrm{ft}$ (41-61 m) in thickness and is composed of gray to white, massive to slightly nodular, chalky and marly, fossiliferous mudstone. The unit often contains grain-rich, thin- to thickbedded glauconitic limestone and marl with fossil fragments. The chalky limestone contains fossil oysters, abundant Inoceramus prisms, foraminifers, and echinoid debris. Bentonite seams and glauconitic pyrite nodules partly weathered to limonite are common. The overlying Anacacho Limestone is greater than $470 \mathrm{ft}$ (143 m) thick and is composed of white to gray mudstone and packstone with thick interbeds of bentonite clay.

A mafic igneous intrusion of fine- to coarse-grained alkali basalt is modeled in the far southwest corner of the study area. The intrusive rocks are identified and described by Blome and others (2004) and Miggins and others (2004).

\section{Model Construction and Methodology}

Data for the hydrogeologic surfaces within the model were identified and defined from three primary sources:

(1) Thirty-one drill holes with stratigraphic picks based on geophysical logs, core, and (or) cuttings.

(2) HEM data were used to help define locations and displacement of faults and interpret and define the tops of two electrically conductive stratigraphic units: the Del Rio Clay and the Eagle Ford Formation. Elevations of top surfaces of these units were validated with geophysical logs from selected drillhole and lithologic descriptions from drill-hole core. HEM data also were used to validate the spatial location for parts of the Devils River Formation by showing what appear to be two geophysical conductivity signatures within the formation. Inadequate subsurface and surface information and inconsistent drilling reports prevent verification of the HEM data within the Devils River Formation for this model.

(3) Contacts defined from surface geologic mapping and local field checking of fault locations and stratigraphic contacts at the 1: 24,000-scale.

Data points for all modeled surfaces are labeled in the data files with one of the following: (1) a drill-hole name or a line number such as TD6938601 or 10050; (2) an "m" designation such as $\mathrm{m} 50$. These data are defined as stratigraphic contact data or calculated data from known contact or drill-hole information; (3) an "md" designation such as md48. These data were needed to help with the computations for the modeled surfaces, especially for displacements along faults. We kept these data points to a minimum.

The primary reference surface for the model is the top of the Del Rio Clay. This surface was selected because it was easily identified in drill-hole data and HEM surveys. The HEM surveys provided a lot of data covering a large area in the central part of the model. The HEM surface was validated using drill-hole geophysical logs. We also used the top of the Glen Rose Limestone as a secondary reference surface to build the model on and to provide a foundation for modeled structure. A critical data source was drill hole YP-69-37-402 in the west-central part of the model, locally known as the Sabinal drill-hole (Small and Maclay, 1982). This drill hole was continuously cored and serves as the local stratigraphic reference for all surfaces. Average thickness of modeled units 
based on the "Sabinal" core and field mapping are: Del Rio Clay, $60 \mathrm{ft}$ (18 m); Buda Formation, $70 \mathrm{ft}$ (21 m); Eagle Ford Formation, $40 \mathrm{ft}$ (12 m); and the Devils River Formation at $500 \mathrm{ft}(152 \mathrm{~m})$ in the western part of the model, thickening eastward to $600 \mathrm{ft}(183 \mathrm{~m})$.

EarthVision $^{\mathrm{TM}}$ modeling software was used to create three-dimensional mathematically defined surfaces from scattered $\mathrm{x}, \mathrm{y}$, and $\mathrm{z}$ data points where $\mathrm{x}$ and $\mathrm{y}$ are a Universal Transverse Mercator (UTM), NAD 27, Zone 14 location in meters, and $\mathrm{z}$ is an elevation in feet. In the model, $\mathrm{x}, \mathrm{y}$, and $\mathrm{z}$ values define top surfaces of lithologic units. Volumes of units are defined and shown as the space between two surfaces and surfaces and fault planes or model extents. EarthVision ${ }^{\mathrm{TM}}$ software follows basic geologic rules to define depositional, channel fill, or unconformable contacts and surfaces. These rules can be modified by adding data points to a surface, altering gridding parameters or detail, or using smoothing algorithms in any or all of the $\mathrm{x}, \mathrm{y}$, or $\mathrm{z}$ dimensions. This allows considerable discretion to define or refine a surface. Modeled surfaces were derived using "minimum surface-tension" gridding algorithms, gridding modifications and detail modifications, and user-defined data points. Details of the algorithms and how data points are used by the software are beyond the scope of this report but are available from Dynamic Graphics, Inc., at http: //www.dgi.com.

EarthVision $^{\mathrm{TM}}$ software was used to create, compile, and display the model because of its ability to use and view different data types. In addition, it can accurately define and show faulted geologic surfaces while maintaining structural complexity and integrity in three dimensions. The model has 25 faults and fault segments. Faults were located using the geologic map of Blome and others (2004) and HEM interpretations (Smith and others, 2003). Location and displacement of faults were cross validated by using field observations, HEM data interpretations, and drill-hole information. Faults were defined as normal and nearly vertical on the basis of our field mapping and the recognized extensional movements of faults within the Balcones fault zone (Barker and others, 1994; Maclay, 1995; and Collins, 2000).

The geologic units modeled occur west to east in the study area. Erosion removed parts of younger units in the northern one-half and along the eastern margin of the study area. For example, the Del Rio Clay crops out and underlies units in the central and southern one-half of the study area but does not exist in the northern or eastern part of the study area. The model prototype was built using subsets of all available data adopted by consensus of the authors. Accurate modeling of structure was critical to develop the model so 10 faults were chosen to prototype the modeling process. The model evolved using an iterative methodology to integrate different data sets and define relationships between stratigraphic surfaces and faults. Some data sets were often limited to different parts of the study area. For example, drill-hole data are scattered throughout the southern one-half of the model, greater accuracy of surface mapping occurs in the northern one-half of the model area, and HEM data for two clay-bearing units are greater in the central part of the study area. Data sets and information were cross-checked against each other. For example, the Del Rio Clay surface elevations built from HEM data were validated by the Del Rio Clay elevations shown on drill-hole logs and geologic maps. As more data were added to the model, interpretations of stratigraphy and structure were refined, and the model evolved, increasing in complexity. The resultant model is the accumulation of interpretations through consensus of the authors as constrained by the data.

Topography for the model was created using U.S. Geological Survey 10-meter Digital Elevation Model (DEM) data. Detail of the surface is a result of the volume of data present, the size and number of grid cells used in the model, and resolution used to display the whole model. We designed the model to show topographic and structural detail. However, we also balanced this with what can be interactively displayed on a typical Intel ${ }^{\mathrm{TM}}$ single processor computer system running Windows $\mathrm{XP}^{\mathrm{TM}}$ as defined in the readmel.txt file on this disc.

Where possible, surfaces were defined using data points defined by surface contacts, drill-hole stratigraphic identification, or HEM data. Where data were missing, data points were mathematically derived from known data points based on local thickness of modeled units or average thickness based on reference well YP-69-37-402. For example, if only local data for a surface was the contact defined on the geologic map, we used the $\mathrm{x}, \mathrm{y}$, and $\mathrm{z}$ values for the mapped surface contact. Local overlying and underlying surfaces were than derived by maintaining the $\mathrm{x}$ and $\mathrm{y}$ location of the mapped contact and calculating the $\mathrm{z}$ elevation value based on local thickness where possible, or average thicknesses based on YP-69-37-402. This held true for elevations of units defined by drill-hole data or HEM data. In the subsurface, some $\mathrm{x}$ and y coordinates were moved slightly to maintain geometry of faults. This was necessary because we had no downhole positioning coordinates for any subsurface stratigraphic units. Because these data points were derived from reference data, they were assigned an " $m$ " label in the data files. Where needed, data points were estimated and added to a surface data file to refine known relationships such as fault displacements or to help the mathematical generation of a surface. These data points have an "md" label in the data sets. Local stratigraphic surface and thickness variations of units were expected and modeled. Such variations may reflect faulting, dissolution, and collapse features or inherent uncertainties of defined picks from geophysical logs or other data. The greatest local variations occur in surfaces defined by HEM data due to the high spatial density of data and system noise and sensitivity of the geophysics modeling process. For the model, HEM data were filtered to limit noise and spikes caused by local anomalies. The authors believe that thickness variations shown in the model reflect reasonable interpretations based on the objective criteria in surface maps, drill-hole log interpretations, lithologic descriptions, observations of drill-hole core, and HEM interpretations. 
The lowermost unit modeled is the Glen Rose Limestone, the lower confining unit of the Edwards aquifer. The top of the Glen Rose is defined by surface mapping in the northern one-half of the study area and was calculated from drill-hole geophysical logs or defined by reference data that defined the surface of the Del Rio Clay. The top of the upper Glen Rose Limestone was used as secondary reference surface because it provided the base to build the model on and was constrained by reference data. As the bottommost unit in the model, the top surface of the Glen Rose Limestone influences positions of overlying units in three-dimensional space, such as the Devils River Formation. Top of the Glen Rose was also used to propagate and validate fault structures defined and shown on geologic maps and HEM interpretations. This was necessary because the software defines fault displacement from modeled surfaces and propagates the displacement until other data are available or some model extent or boundary is reached.

The Del Rio Clay is well defined by HEM geophysical conductivity, drill-hole, geophysical, and lithologic data. The Eagle Ford Formation HEM data were used to calculate top of the Del Rio Clay in the southern one-third of the study area because the HEM survey did not penetrate the stratigraphic unit due the volume of clay. An approximate top for the Del Rio Clay was extrapolated from the top of the Upper Glen Rose Limestone in the northern one-third of the study area. This extrapolated surface helped validate geologic map contacts on hill and mesa tops and as an aid to model other geologic units and structures. The top of the Del Rio Clay was used as the primary reference surface because of the abundance of data, certainty of picks, and interpretations from known reference points. This surface was used to help define overlying and underlying units where data were sparse. Because of the abundance and accuracy of HEM data for this surface and the overlying Eagle Ford Formation, these surfaces show more local variation in the model.

The Buda Formation in the model was defined with a thickness of 70 feet, or as the volume between the top of the Del Rio Clay and the bottom of the Eagle Ford Limestone, using the top of the Del Rio Clay as its reference horizon. HEM data could not be used to build the Buda Formation surface because HEM signals cannot penetrate thick, electrically conductive clay-bearing units such as the overlying Eagle Ford Formation. However, HEM soundings did show the Buda Formation where exposed.

The combined Austin-Anacacho unit is the upper surface shown in the southern one-half of the model. Topography for the model was defined using USGS 10-meter topographic DEM data. EarthVision ${ }^{\mathrm{TM}}$ software was used to create a detailed topographic grid. This grid was used to truncate modeled units to build the topographic surface. The topographic surface shows the approximate location of exposed geologic and hydrogeologic units and is an aid to locate these units on topographic maps.

All data were evaluated for quality and accuracy by using two- and three-dimensional visual analysis and modeling and by field checking surface outcrops. All data types were iteratively cross-checked against each other. Due to the iterative and visual nature of the model, data inconsistencies were identified early in the modeling process and resolved. The results of the ongoing visual evaluations are a better understanding of the geology and structure in the study area as well as increased model accuracy.

\section{Structural Uncertainties in Southeastern Part of Model}

The existence of faults parallel to the Seco Creek drainage south of the intersection of Cedar Creek and Seco Creek has been questioned for decades. Historically, the U.S. Geological Survey (USGS) started mapping the upper Seco Creek area of Medina and Uvalde Counties in the early 1930s (Sayre, 1936, pl. 1). Their published results and recent mapping by the USGS and the Texas Bureau of Economic Geology (TBEG) show that the local bedrock geology is obscured by undifferentiated Quaternary terrace deposits and Pleistocene Leona Formation gravels; in addition, erosion and a lack of surface or subsurface drill-hole evidence neither prove nor disprove the existence of local faults. Because of years of speculation, the authors believe a brief history about the existence of a local fault or faults is warranted.

Arguments for faulting:

- Sayre (1936, pl. 1) inferred a possible cross-fault that cuts across Seco Creek. This fault, located near the Medina and Uvalde County boundary in the area of Little Seco and Seco Creeks, was inferred to offset the younger Eagle Ford and Austin Groups and Anacacho Formation against the older Buda Formation.

- Small and Clark (2000) show undifferentiated Devils River Formation rocks faulted along the Seco Creek drainage and against the much younger gravels of the Leona Formation in the same area.

- 1: 75,000-scale mapping by Clark and others (2006) along Seco Creek shows an inferred cross-fault informally named the "Seco Creek Valley fault" bounded by the Woodard Cave fault to the north and the Parker Creek fault to the south.

- Clark and Journey (2006) suggest that a fault forms at least a partial barrier to waterflow because an offset of several hundred feet of the Edwards aquifer and juxtaposed confining units might direct part or most of the waterflow southward.

- Geophysical soundings used for this model show that reflections from the the Del Rio Clay end in the Seco Creek drainage-a lateral discontinuity that may suggest a local fault.

Arguments against faulting: 
- C.L.R. Holt, Jr. (1959, pl.1), in cooperation with the Texas Board of Water Engineers, does not show any cross-faults along Seco Creek. Also shown are the Leona Formation gravels overlying the other lithologic units.

- Collins (1999a, b) mapped the geology along Seco Creek in the Flatrock Crossing 7.5-minute quadrangle and did not include a cross-fault in the Seco Creek drainage south of its intersection with Cedar Creek.

- Recent mapping by Blome and others (2004) shows no faults along the Seco Creek drainage.

- The west and southwest dip of the Eagle Ford Formation under the Leona gravels and Quaternary gravels, the Buda Formation, and thinner parts of the Austin Group as shown in the HEM data and drillhole data and by surface geologic mapping would position the Eagle Ford Formation at the surface along Seco Creek. This, coupled with erosion, may explain why the Eagle Ford Formation and Del Rio Clay abruptly end east of Seco Creek locally.

- HEM data show local faults that are not shown on surface geologic maps, under alluvium deposits in parts of the study area (Smith and others, 2003). The data also infer that the Eagle Ford Formation and Del Rio Clay dip east and southeast in cross section. In cross section, this dip shows the Del Rio Clay cropping out along Seco Creek in the area of the controversial fault. Erosion, perhaps caused by events that deposited the Leona Formation gravels and local terraces, may account for the abrupt termination of the Eagle Ford Formation and the Del Rio Clay.

\section{Modeled Structure}

We developed both a model without the controversial fault and one with the northwest-trending cross-fault. Both models show the Del Rio Clay ending in the Seco Creek drainage. This model includes the cross fault. The fault location inferred from study of the HEM data is south of the intersection of Cedar Creek with Seco Creek, in the Seco Creek drainage along a line where data for the Del Rio Clay end (fig. 3). Fault placement is west of the current location of Seco Creek and west of where others inferred a fault (Sayre, 1936, pl. 1; Small and Clark, 2000; Clark and others, 2006; and Clark and Journey, 2006). HEM data further constrain a possible fault location between the Seco Valley Road fault to the north and the Parker Creek fault to the south.

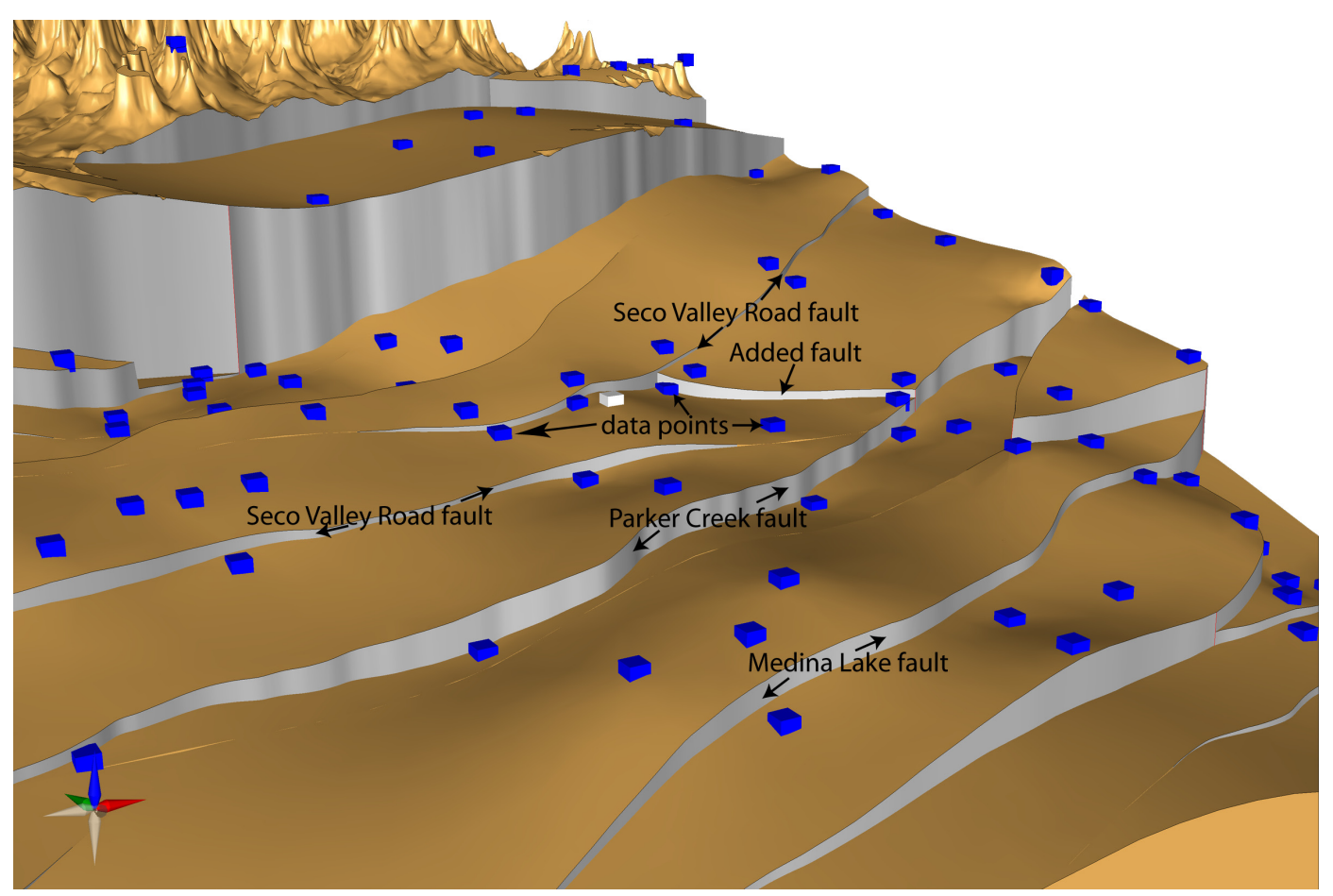

Figure 3. Surface of the Glen Rose Limestone showing the inferred north-trending fault bounded by the discontinuous Seco Valley Road fault on the north and the continuous Parker Creek fault on the south. View is toward the northeast. 
To model the fault, we created data points east of where the HEM data for the Del Rio Clay ended. We modeled a maximum displacement of about 50 feet, or the approximate thickness of the Del Rio Clay; this displacement is similar to other local fault displacements. In addition, more than 50 feet of displacement caused problems with known stratigraphic surfaces and the spatial relationships between faults and stratigraphic surfaces that are known to exist by geologic maps, drill-hole data, and HEM data to the north, south, east, and west. Though the fault provides an abrupt termination of the Del Rio Clay surface, models without the fault showed the Del Rio Clay terminating in the same area.

\section{Conclusions}

Evolving this model both visually and interactively simplified the integration of the data. The model is internally consistent because drill-hole geophysical and lithologic data were used to confirm HEM and surface geologic data; surface geologic data were used to confirm HEM and drill-hole data, and HEM data were used to confirm drill-hole and surface geologic data. The resultant model is a more accurate interpretation due to the diversity of the data used and the integration and cross validation of the different types of data. The model shows the complex relationships between fault-bounded lithologic units, possible downgradient flow pathways along or across fault boundaries, and tilted and fractured ramplike structures that resulted from faulting in this part of the Balcones fault zone. The interactive nature of this model makes it an excellent tool to study these relationships and the relationships of other data sets in the modeled area.

HEM data for the Eagle Ford Formation and the Del Rio Clay in the center part of the model help identify and accurately locate faults shown by Blome and others (2004). An area of importance is the west-central part of the model, south of the Woodard Cave fault. In this area, fewer faults were seen in the data at shallow depth, and faults that were retained are based on interpretations of drill-hole geophysics and HEM surveys. Faults modeled were traced across flight lines until they faded out. Several named faults in the central part of the model were relocated based on HEM data. Locally, location adjustments of some faults exceeded one-half mile. Of note was the Seco Valley Road fault. Although inferred to be continuous by published maps, the HEM data showed a break in the continuity of the fault in the central part of the model. Even with these modifications, overall structural trends are consistent with mapping done by Blome and others (2004), by Collins (1998, 1999a, 1999b), and in other earlier works.

Major structural trends and outcrop of this model are mostly consistent with the mapping done by Blome and others (2004). Differences in the details are seen for the following reasons: some faults were removed or their locations changed, faults were added because of the interpretation of HEM data that showed fault locations at shallow depth, the modeled DEM surface is less detailed than the original DEM, and there are limits to the detail the software can model. Also, we chose to show less surface detail to keep the model robust on commonly available hardware.

\section{References Cited}

Barker, R.A., Bush, P.W., and Baker, E.T., Jr., 1994, Geologic history and hydrogeologic setting of the Edwards-Trinity aquifer system, west-central Texas: U.S. Geological Survey Water Resources Investigations Report 94-4039, 51 p.

Blome, C.D., Faith, J.R., Collins, E.W., Pedraza, D.E., and Murray, K.E., 2004, Geologic map compilation of the upper Seco Creek area, Medina and Uvalde Counties, southcentral Texas: U.S. Geological Survey Open-File Report 2004-1430, 21 p., 1 pl., scale 1: 50,000.

Clark, A.K., 2003, Geologic framework and hydrologic characteristics of the Edwards aquifer, Uvalde County, Texas: U.S. Geological Survey Water-Resources Investigations Report 2003-4010, 17 p, 1 pl., scale 1: 75,000.

Clark, A.K., Faith, J.R., Blome, C.D., and Pedraza, D.E., 2006, Geologic map of the Edwards aquifer in northern Medina and northeastern Uvalde Counties, southcentral Texas: U.S. Geological Survey Open-File Report 2006-1372, 22 p., 1 pl., scale 1: 75,000.

Clark, A.K., and Journey, C.A., 2006, Flow paths in the Edwards aquifer, northern Medina and northeastern Uvalde Counties, Texas, based on hydrologic identification and geochemical characterization and simulation: U.S. Geological Survey Scientific Investigations Report 2006-5200, 48 p.

Collins, E.W., 1997, Geologic map of the Texas Mountain quadrangle, Texas: University of Texas at Austin, Bureau of Economic Geology Open-File Map, scale 1: 24,000.

Collins, E.W., 1998, Geologic map of the Sabinal NE quadrangle, Texas: University of Texas at Austin, Bureau of Economic Geology Open-File Map, scale 1: 24,000.

Collins, E.W., 1999a, Geologic map of the Comanche Waterhole quadrangle, Texas: University of Texas at Austin, Bureau of Economic Geology Open-File Map, scale 1: 24,000.

Collins, E.W., 1999b, Geologic map of the Flatrock Crossing quadrangle, Texas: University of Texas at Austin, Bureau of Economic Geology Open-File Map, scale 1: 24,000. 
Collins, E.W., 2000, Geologic map of the New Braunfels, Texas, 30 × 60 minute quadrangle-Geologic framework of an urban-growth corridor along the Edwards aquifer, southcentral Texas: University of Texas at Austin, Bureau of Economic Geology Miscellaneous Map No. 39, 28 p., 1 pl., scale 1: 100,000 .

Holt, C.L.R., Jr., 1959, Geology and ground-water resources of Medina County, Texas: U.S. Geological Survey watersupply paper 1422 , prepared in cooperation with the Texas Board of Water Engineers, 213 p., 6 pl.

Lozo, F.E., Jr., and Smith, C.I., 1964, Revision of Comanche Cretaceous stratigraphic nomenclature, southern Edwards Plateau, southwest Texas: Gulf Coast Association of Geological Societies Transactions, v. 14, p. 285-306.

Maclay, R.W., 1995, Geology and hydrology of the Edwards aquifer in the San Antonio area, Texas: U.S. Geological Survey Water Resources Investigations Report 95-4186, $64 \mathrm{p}$.

Miggins, D.P., Blome, C.D., and Smith, D.V., 2004, Preliminary ${ }^{40} \mathrm{Ar} /{ }^{39} \mathrm{Ar}$ geochronology of igneous intrusions from Uvalde County, Texas: Defining a more precise eruption history for the southern Balcones Volcanic Province: U.S. Geological Survey Open-File Report 2004-1031, 31 p.

\section{Disc Contents}

In addition to this discussion, this publication contains a complete faulted 3-D surface and volume model with supporting digital data sets of stratigraphic units and HEM information in the study area. The data sets include drill-hole from core and geophysical logs, surface geology and elevation, and HEM data. The model may be explored and .jpg or .tiff images saved of user-defined views. Both a basic "getting started" help file by Pantea and Cole (2004) and detailed help files are provided as aids to understanding the 3-D viewer. We included viewers for Windows XPTM, Linux, and SUNTM platforms. However, the SUNTM platform requires additional drivers available from SUN ${ }^{\mathrm{TM}}$. Once in the viewer program, all functions operate the same. The USGS has licensed the rights from Dynamic Graphics, Inc., to provide an encrypted model and the viewers to use the enclosed data sets and interpreted model. The license allows the USGS the service and rights to provide unlimited distribution. We designed this product to function from the DVD-ROM media but recommend the necessary files be copied to a local hard drive for better performance. No additional installation programs are needed to view the model and data sets using the 3-D viewer. More information about the viewing software and EarthVision ${ }^{\mathrm{TM}}$ may be obtained from Dynamic Grapics, Inc., at http: //www.dgi.com.
Pantea, M.P., and Cole, J.C., 2004, Three-dimensional geologic framework modeling of faulted hydrostratigraphic units within the Edwards aquifer, northern Bexar County, Texas: U.S. Geological Survey Scientific Investigations Report 2004-5226, CD-ROM.

Sayre, A.N., 1936, Geology and ground-water resources of Uvalde and Medina Counties, Texas: U.S. Geological Survey Water-Supply Paper 678, 146 p.

Small, T.A., and Clark, A.K., 2000, Geologic framework and hydrologic characteristics of the Edwards aquifer outcrop, Medina County, Texas: U.S. Geological Survey WaterResources Investigations Report 2000-4195, 10 p, 1 pl.

Small, T.A., and Maclay, R.W., 1982, Test-hole data for the Edwards aquifer in the San Antonio area, Texas: Texas Department of Water Resources LP-171, 153 p.

Smith, B.D., Smith, D.V., Hill, P.L., and Labson, V.F., 2003, Helicopter electromagnetic survey of the Seco Creek area, Medina and Uvalde Counties, Texas: U.S. Geological Survey Open-File Report 2003-226, 47 p.

Stricklin, F.L., Jr., and Amsbury, D.L., 1974, Depositional environments on a low-relief carbonate shelf, middle Glen Rose Limestone, Central Texas: Baton Rouge, Louisiana State University, Geoscience and Man, v. 8, p. 53-67.

Publishing support provided by:

Denver Publishing Service Center

For more information concerning this publication, contact: Team Chief Scientist, USGS Earth Surface Processes Box 25046, Mail Stop 980

Denver, CO 80225

(303)236-5344

Or visit the Earth Surface Processes Team Web site at: http://esp.cr.usgs.gov/ 
흥

容

1

高

을

응.

ق

D

응.

$\frac{3}{3}$

옹

음

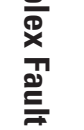

营

恋

is

咅

Ф़

$\vec{P}$

|

cs

ब.

言

胥

웜

함.

क

규

욱

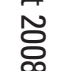

崩 